해외기술자료

\title{
$\mathrm{ADC}$ 합금 다이캐스트중의 개재물이 기계적 특성에 끼치는 영향 ${ }^{1)}$
}

\author{
高木航 *・吉田誠 ** \\ *早稻田大學大學院創造理工學研究科, **早稻田大學各務記念材料技術研究科
}

\section{Effect of Inclusions on Mechanical Properties of ADC12 Alloy Die Castings}

\author{
Kou Takagi* and Makoto Yoshida** \\ * Graduated school of Creative Science and Engineering, Waseda University \\ **Waseda University, The Kagami Memorial Laboratory for Materials Science
}

Key words: ADC12, Die Casting, Aluminum alloy, Inclusion, Cold flakes.

\section{1. 서 론}

전보 [1]에 있어서, 다이캐스팅 프로세스 중 $\{$ 원탕 $\rightarrow$ 레이 들 $\rightarrow$ 슬리브 $\rightarrow$ 주입구 $\rightarrow$ 제품부 $\rightarrow$ 오버플로우 $\}$ 에 있어 개재 물량을 해당 $\mathrm{K}$ 값을 계측하는 것으로 조사했다. 그 결과로부터, 다이캐스팅 프로세스 중에 개재물이 늘어나는 것은 물론, 게이 트 통과시에 개재물, 파단칠층이 파괴되어 작아지는 것을 알았 다. 이것은 자칫하면, 유지로 중의 $\mathrm{K}$ 값을 낮게할 필요가 없기 때문은 아닐까라고 하는 해석을 낳는 우려가 있고, 그 진위를 확인할 필요가 있다.

그래서 본 연구에 있어서는, 유지로의 $\mathrm{K}$ 값이 높고, 또 파단 칠층이 원래 많아도 기계적 특성에 영향을 끼치지 않을까를 확 인했다. 구체적으로는, 숏타임래그(Shot Time Lag. 이하 STL 라 한다), 개재물량, 사출속도, 윤활재등의 다이캐스팅 조건을 바꾸어, $\mathrm{ADC} 12$ 합금 다이캐스팅의 기계적 특성에 끼치는 영 향을 조사했다. 또, 후술한 루트영역(root area)법을 사용해서, 기계적 특성에 영향을 끼치지 않는 개재물 면적이 어느 정도일 까를 검토했다. 최후에, 파면중의 개재물의 원소분석을 행하여, 그 정체를 찾았다.

\section{2. 루트영역법에 대해서}

본장에서는, 개재물의 크기와 기계적 특성과의 상관을 고려한 후 사용한 루트영역법의 개념에 대해서 종래의 연구를 정리했다.

\section{1 루트영역과 기계적 특성과의 상관}

村上들 [2]은 연구 중에서, 피로 강도에 끼치는 결함의 영향 은, 결함의 형상, 치수, 방향 및 위치에 따라서 다르다고 보고 하고 있다. 결함의 영향에 대해서 통일적인 정량적 평가법을 확립하기 위해, 여러 가지 삼차원 균열에 일어나는 응력확대계 수의 형상의존성에 대해서의 특징을 명확히 하고, 피로강도에 영향을 미치는 지배적 형상 변수를 예측했다.

결함재의 피로한이란, 결함에서 균열이 발생하는지 안하는지 의 한계가 아니고, 결함에서 발생한 균열이 살짝 전파해 정지 하고, 그것이 진전하는지 않는지의 한계이다. 이 거동을 가장 강하게 지배하는 것은, 제일근사로 해서 응력확대계수일 것이라 고 村上등은 추측하고 있다.

村上등은 여러 가지 절대치수와 형상비에 대하여 응력확대계 수의 최대치를 가장 잘 근사 가능한 대표 치수는, 균열면적의 평방근(이후 $\sqrt{a r e a}$ 라 쓴다)인 것을 명백히 했다.

Fig. 1은 그 관계를 나타낸 것이다 [2]. 가로축은 반경 1 의 단위원 면적의 평법근( $\sqrt{\text { area }})$ 을 척도에 두고 있고, 세로축은 무차원 응력확대계수이다. 그림에서 알 수 있듯이 $\mathrm{a} / \mathrm{b} \leqq 5$ 에서 는 다음의 식이 거의 성립한다.

$$
K_{I} \propto(\sqrt{\text { area }})^{1 / 2}
$$

area $=$ 결함을 최대주응력방향에 수직한 면으로 투영한 면적

또. 파선 $\mathrm{D}$ 에서 나타내듯이, $\mathrm{a} / \mathrm{b}>5$ 에서는, $(\sqrt{\text { area }})^{1 / 2}$ 에 비례하지않고, $K_{\mathrm{I}}$ 은 포화한다.

\footnotetext{
1) 日本鑄造工學會誌 제 83권(2011) 제10호 page 586 592에 게재된 자료임.

2)아주대학교(Ajou University) 기초교육대 교추
} 


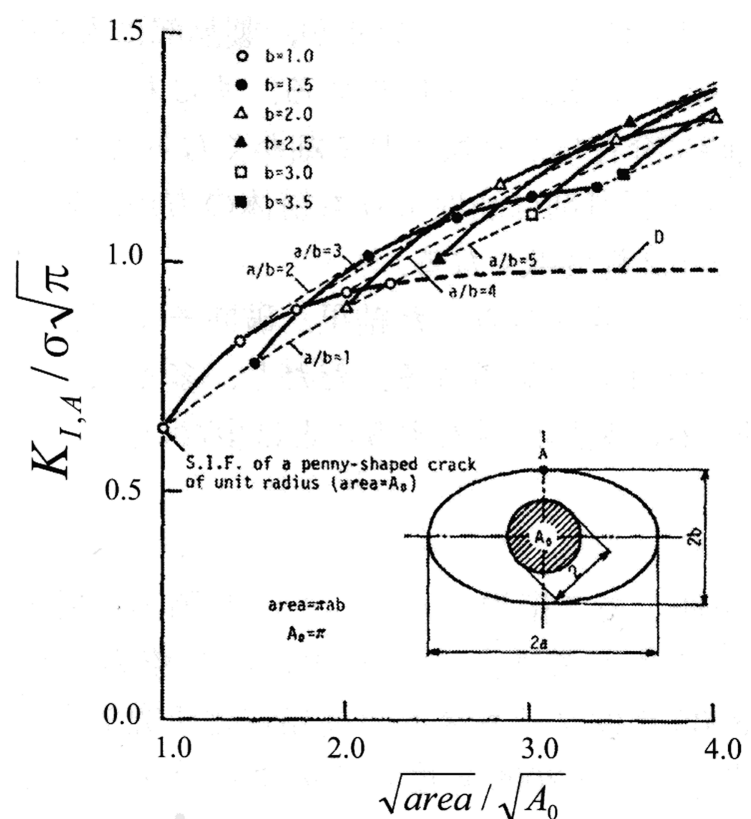

Fig. 1. 응력확대계수와 균열면적의 평방근관계(타원판상균열).

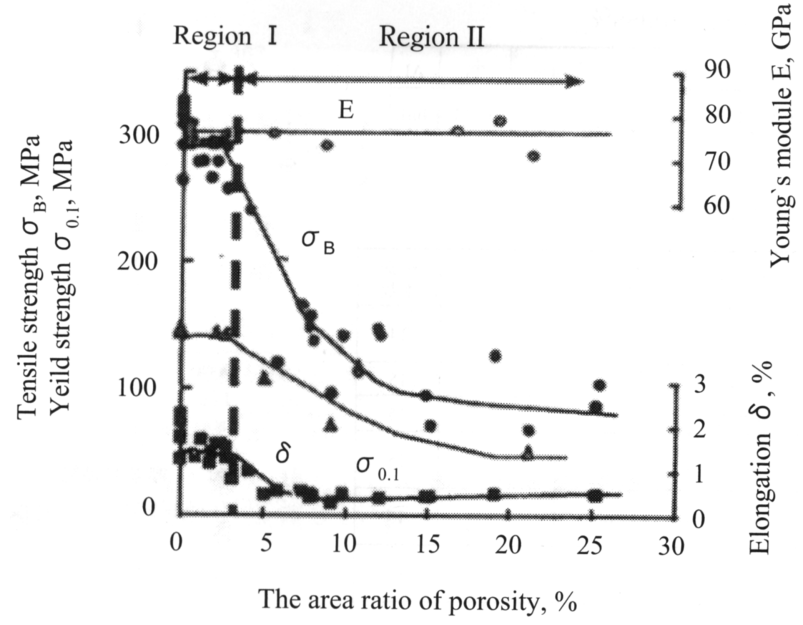

Fig. 2. 기계적 특성과 결함면적율과의 관계.

균열은 대부분의 경우, 최대주응력에 수직방향으로 전파해 정 지하는 것에서, 피로한의 상태는 결함을 최대주응력방향으로 수 직면에 투영한 면적에, 새롭게 결함으로부터 발생한 균열 면의 면적을 더한 합계 면적의 균열이, 최초부터 존재했던 경우와 거의 등가로 생각하는 것이 가능하다. 村上등은 일반적으로, 미 소결함에서 발생하고 정지했던 균열은, 그렇게까지 길지 않고 면적도 작기 때문에, 결함을 최대주응력에 수직한 면에 투영한 면적을 대표면적으로 해도 좋다고 결론내고 있다.

이상으로부터, 村上등은 이하와 같이 정리하고 있다.

- $\sqrt{a r e a}$ 은, 피로강도를 추정하기위해 중요한 파라매타이며, 삼차원적인 균열 또는 결함의 대표 치수로 간주하는 것이 가능
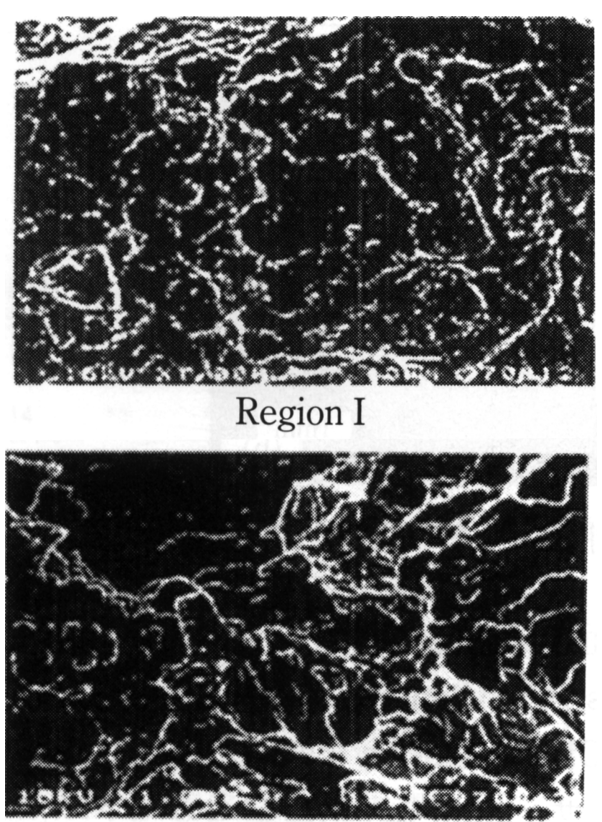

Region II

Fig. 3. 파괴기점부 근방의 파면사진.

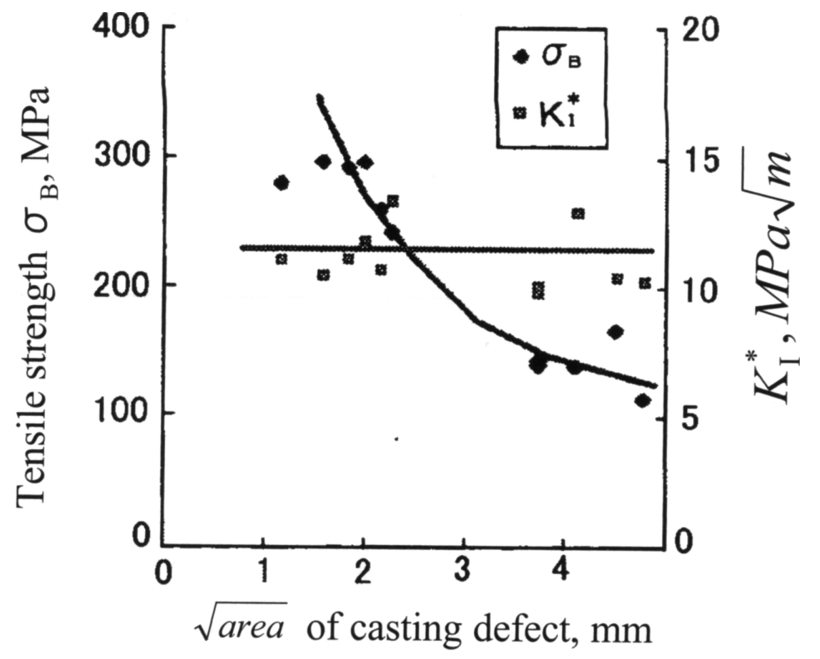

Fig. 4. $\sigma_{\mathrm{B}}, K_{\mathrm{I}}^{*}$ 와 $\sqrt{\text { area }}$ 의 관계.

하다. 특히, 응력확대 계수의 최대치 $K_{\mathrm{I}}$ 이란 $K_{I} \propto(\sqrt{\text { area }})^{1 / 2}$ 의 관계가 있다.

山田등은 $\mathrm{ADC12}-\mathrm{F}$ 를 사용해서 인장시험을 행하고, 인장 강도, 파단신율, $0.1 \%$ 내력 및 영률과 수축공의 결함면적율(결함 의 인장축에 직향하는 면에의 투영면적의 합이 단면적에 차지하 는 비율)의 관계를 나타냈다. 그 상관을 Fig. 2에 나타낸다 [3].

Fig. 2를 보면, 결함면적율의 증가에 따라, 인장강도, 파단신 율 및 $0.1 \%$ 내력이 감소하고, 영률은 일정치를 나타내고 있다. 인장강도와 결함면적률의 관계를 상세하게 보면, 인장강도에는 결함면적률에 영향을 받기 어려운 영역(영역I)과, 영향을 받기 
쉬운 영역(영역II)이 존재하는 것을 알 수 있다.

Fig. 3에 영역I에서 파탄한 시료의 파면과, 영역II에서 파단 한 시료의 파면의 비교화상을 나타낸다 [3]. 영역I의 파면에는 일부 팀플이 확인되어지는 것에 대해, 영역II의 수축공 주변의 파면은 취성의 파면을 나타내고 있다.

파괴기점부의 결함치수와 인장강도에 의해, 이하의 식에서 구 한 $K_{\mathrm{I}}^{*}$ 은 주조소, 응고편, 인공결함과 같은 결함의 종류에 따 르지 않고 거의 일정이고, $K_{\mathrm{IC}}(\mathrm{J}), K_{\mathrm{IC}}$ 와 거의 같다고 山田등은 보고하고 있다. 결함면적 $(\sqrt{a r e a})$ 과 인장강도와 $K_{\mathrm{I}}{ }^{2}$ 과의 관계를 Fig. 4에 나타난다 [3].

$$
K_{I}^{*}=\beta \sigma_{B} \sqrt{\pi \sqrt{\text { area }}}
$$

$\sqrt{\operatorname{area}}$ : 최대주응력에 수직면에 투영한 균열면적의 평행근 $\beta$ : 균열이 표면에 접하는 경우 0.67 균열이 표면위에 존재하는 경우 0.65 균열이 내부에 존재하는 경우 0.50

이상의 결과에 따라, 山田등은 이하와 같이 정리하고 있다.

- 결함면적률에 영향을 받을 만한 시험편의 결함근방조직은, 취성의 파면을 나타내고 있다.

- $K_{\mathrm{I}}^{*}$ 은 결함의 종류에 의하지 않고(결함면적에 의존하지 않 는다 $)$, 거의 일정치 $\left(\fallingdotseq K_{\mathrm{IC}}\right)$ 가된다.

\section{3 루토영역법에 대해서의 정리}

루토영역법에 대해서의 종래 연구를 정리하면, 이하와 같이 된다.

- $\sqrt{a r e a}$ 는, 피로강도를 추정하기 위해서 중요한 파라매터이 고, 삼차원적 균열 또는 결함의 대표 치수로 간주하는 것이 가 능하다. 특히, 응력확대계수의 최대치 $K_{\mathrm{I}}$ 란, $K_{I} \propto(\sqrt{\text { area }})^{1 / 2}$ 의 관계가 있다.

- 결함면적률에 영향을 주는 시험편의 결함근방조직이, 취성 의 파면을 나타내고 있다.

- $K_{\mathrm{I}}^{*}$ 은 결함의 종류에 의하지 않고 (결함면적에 의존하지 않 고), $K_{\mathrm{IC}}$ 와 동등의, 거의 일정의 값이 된다.
Table 1. $\mathrm{AD} 12.1$ 합금의 화학조성, $\operatorname{mass} \%$.

\begin{tabular}{lllllllllllll}
\hline $\mathrm{Cu}$ & $\mathrm{Si}$ & $\mathrm{Mg}$ & $\mathrm{Zn}$ & $\mathrm{Fe}$ & $\mathrm{Mn}$ & $\mathrm{Ni}$ & $\mathrm{Sn}$ & $\mathrm{Pb}$ & $\mathrm{Cd}$ & $\mathrm{Cr}$ & $\mathrm{Ti}$ & $\mathrm{Al}$ \\
\hline
\end{tabular}

1.8410 .340 .240 .700 .880 .150 .050 .020 .050 .000 .040 .03 bal.

\section{3. 실험 방법}

\section{1 개재물, 파단칠층의 수가 ADC12 합금 다이캐스트의} 기계적 특성에 미치는 영향

실험에 사용하는 합금은 JIS AD12.1 합금이다. 이번 사용한 합금의 화학조성은 Table 1에 나타낸 것과 같다.

본 실험에서는, 용탕에 첨가된 절분량과 다이캐스팅조건 등을 파라매타로 해서, 인장실험편을 만들어 시험을 행했다. 료비(주) 보유의 도시바기계제 형체력 90 ton 콜드챔버 다이캐스팅 머신 에서 제작한 시험편의 제작조건을 Table 2에 나타낸다.

또한, 유지로에서의 용해률은 약 $70 \mathrm{~kg}$, 유성윤활제에는 스페 셜 $\mathrm{A}$, 분체윤활제에는 하나노 $\mathrm{GW}-61$ 을 사용했다. 또, 인장 시험은 닛산자동차(주)에 의뢰해서 실험해 받았다.

파면관찰에는 와세다대학 재료기술연구소의 줌 현미경(키엔누 제 VHX-900)을 사용했다.

\subsection{ADC12합금중의 개재물 면적이 기계적 특성에 미치 는 영향}

3.1항에서 인장시험을 행한 후의 시험편의 파면을 광학 현미 경에서 관찰하고, 사진을 촬영했다. 그리고, 파괴기점으로서의 개재물을 화상에서 판단하고, 화상해석소프트를 사용해 개재물 면적을 측정했다. 그 측정한 개재물 면적에서 파라매터 $\log _{10} \pi$ $\sqrt{\operatorname{area}}$ 을 계산해, 루트영역 차트를 만들었다. 개재물 면적의 측정예를 Fig. 5에 나타난다.

개재물 면적의 측정에는, 화상해석 소프트로서 Media Cybernetics사제의 Image-Pro Plus 5.0J를 사용했다. 또, 후술 한 $\mathrm{OBA}(\mathrm{Optically} \mathrm{Light} \mathrm{Area)과} \mathrm{그} \mathrm{주변조직의} \mathrm{관찰에는,}$ 열전계방출형 주사전자현미경(JEOL WP JMS-7001F)을 가속 전압 $15 \mathrm{kV}$ 에서 사용했다.

Table 2. 인장시험편의 제작조건.

\begin{tabular}{|c|c|c|c|c|c|c|c|}
\hline 표기 & STL & 사출속도 & 침첨가량 & 윤활제 & $\mathrm{K}$ 값(목측) & 처리방법 & 인장개수 \\
\hline 표준 STL0sec & $0 \mathrm{sec}$ & $1.8 \mathrm{~m} / \mathrm{s}$ & - & 분체 & 2.2 & - & 14 \\
\hline STL $3 \mathrm{~s}$ & $3 \mathrm{sec}$ & $1.8 \mathrm{~m} / \mathrm{s}$ & - & 분체 & - & - & 15 \\
\hline STL $5 \mathrm{~s}$ & $5 \mathrm{sec}$ & $1.8 \mathrm{~m} / \mathrm{s}$ & - & 분체 & - & - & 15 \\
\hline STL 0s 윤활제 유성 & $0 \mathrm{sec}$ & $1.8 \mathrm{~m} / \mathrm{s}$ & - & 유성 & - & - & 15 \\
\hline 개재물 $+1.2 \mathrm{~m} / \mathrm{s}$ & $0 \mathrm{sec}$ & $1.2 \mathrm{~m} / \mathrm{s}$ & $1.6 \mathrm{~kg}$ & 분체 & 12.6 & - & 15 \\
\hline 개재물 $+1.8 \mathrm{~m} / \mathrm{s}$ & $0 \mathrm{sec}$ & $1.8 \mathrm{~m} / \mathrm{s}$ & $1.6 \mathrm{~kg}$ & 분체 & 12.6 & - & 15 \\
\hline 개재물 $++1.8 \mathrm{~m} / \mathrm{s}$ & $0 \mathrm{sec}$ & $1.8 \mathrm{~m} / \mathrm{s}$ & $3.2 \mathrm{~kg}$ & 분체 & 20 & - & 16 \\
\hline 개재물++금망 & $0 \mathrm{sec}$ & $1.8 \mathrm{~m} / \mathrm{s}$ & $3.2 \mathrm{~kg}$ & 분체 & - & 금망 & 10 \\
\hline
\end{tabular}



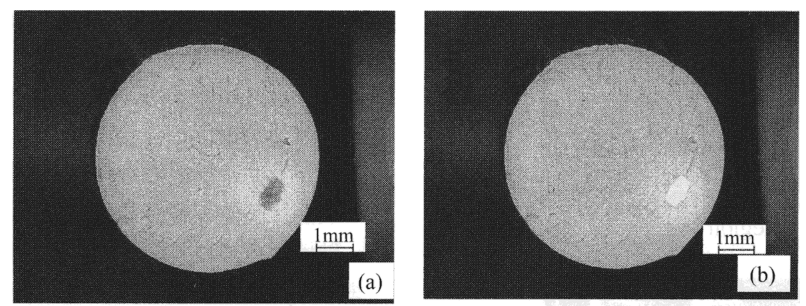

Fig. 5. 개재물 면적의 측정 예. (a) 원사진, (b) 측정시의 도포 사진.

\section{3 개재물의 해석}

개재물이라고 생각된 부분을 중심으로 $\mathrm{SEM}$ 관찰을 행하고, 개재물이라고 생각되는 것(파면중의 이물)을 $\mathrm{EDS}$ 분석(점분석) 했다.

\section{4. 실험 결과와 고찰}

\section{1 개재물, 파단칠층의 수가 ADC12 합금의 기계적 특} 성에 미치는 영향

STL이 길수록, 슬리브 벽면에 냉각 응고한 파단칠층의 생성 량이 많아진다고 생각된다. 또, 절분의 첨가에 따라 개재물의 양이 증가한다고 생각된다. 실제로 개재물을 첨가한 시료의 $\mathrm{K}$ 치를 계측한 결과, 개재물을 첨가할수록 $\mathrm{K}$ 치는 증가 하고 있 다. 용탕을 국자의 금망으로 거르면, 개재물의 양은 저감할 수 있다고 보고되고 있다 [8]. 윤활제의 종류도, 분체의 편이 유성 보다도 용탕과 슬리브 사이의 열전달계수가 작기 때문에, 개재 물량에 영향을 끼친다고 생각되어진다.

$\mathrm{ADC} 12$ 합금에서 다이캐스팅 조건을 변화하여, 인장시험을 행하여, 공칭강도와 파단신율을 측정했다. 그결과를 Fig. 6과 7 에 나타낸다. STLOs는 가장 파단칠층의 양을 억제하고 있다 고 생각되는 다이캐스팅 조건이기 때문에, 공칭 강도와 파단신 율을 평가하는 때에, 표준재로 사용한다.

Fig. 6, Fig. 7에 의해 이하의 것을 알았다.

- STL이 길수록 공칭강도는 감소하고 편차도 커진다.

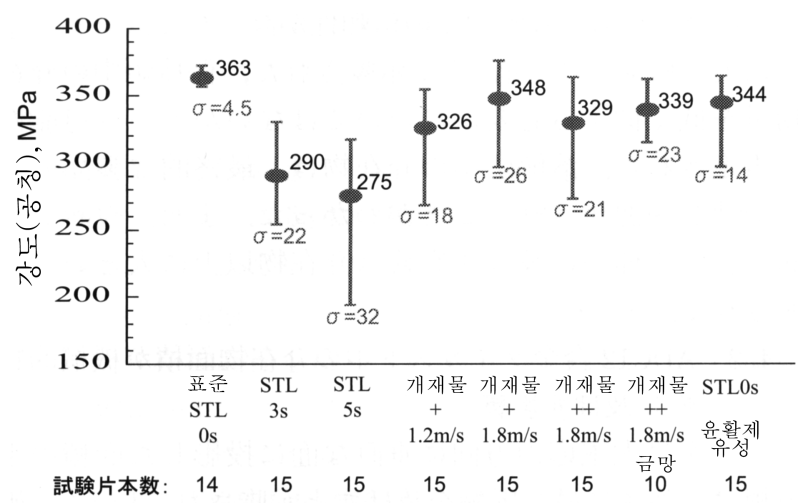

Fig. 6. 개재물이 인장강도(공칭)에 미치는 영향( $\sigma$ : 표준편차).

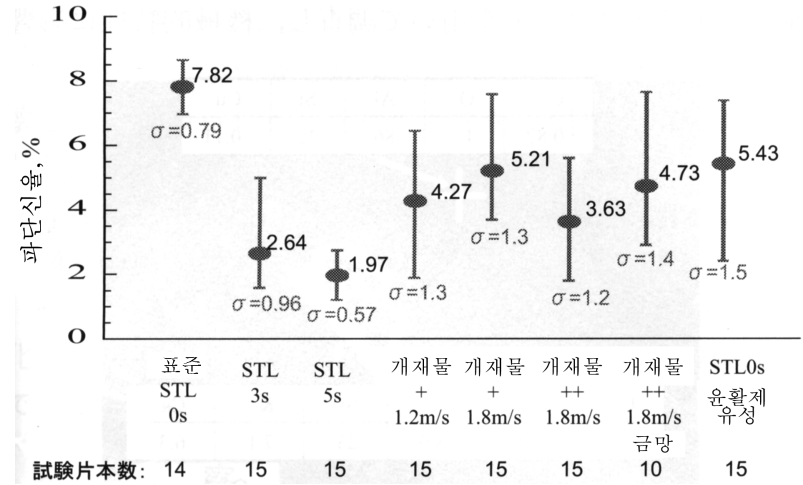

Fig. 7. 개재물이 파단신율에 미치는 영향( $\sigma$ : 표준편차).

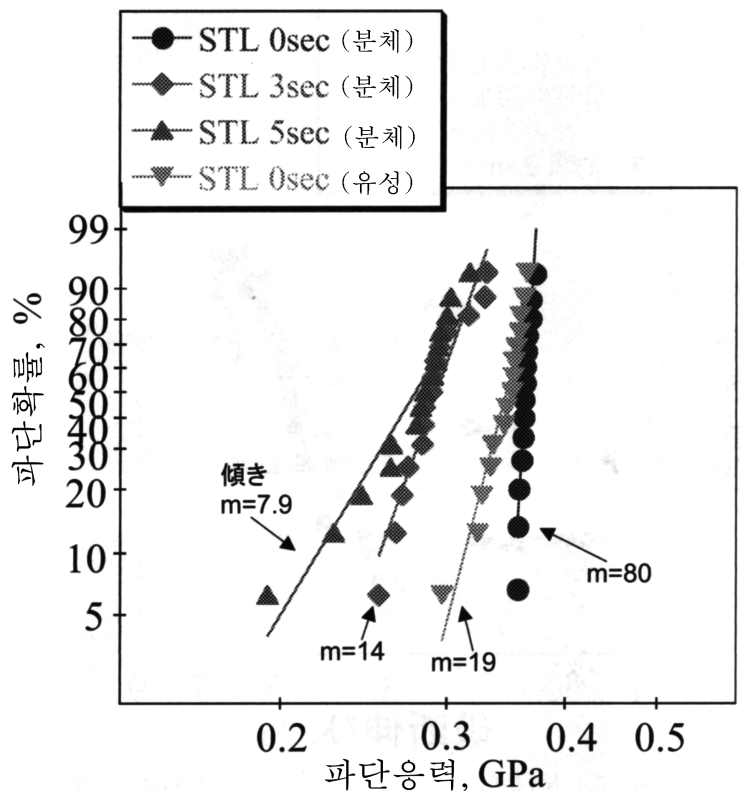

Fig. 8. STL와 윤활제가 인장강도(공칭)의 신뢰성에 미치는 영향.

- 개재물의 양이 많은 만큼 강도는 감소하고 있지만, STL의 변화만큼 강도에 미치는 영항은 크지 않다.

- 금망의 사용에 따라 개재물을 첨가한 채 아무것도 하지 않은 경우보다도 강도는 증가하고, 편차도 감소한다.

- 유성윤활제를 사용하면, 분체윤활제를 사용했던 때보다, 강 도는 감소하고, 편차도 커진다.

- STL이 긴만큼, 파단신율은 감소하고, 편차도 커진다.

- 개재물의 양이 많을수록 파단신율이 감소하고있지만, STL 의 변화만큼 파단신율에 끼치는 영향이 크지 않다.

- 금망의 사용에 따라 개재물을 첨가한 채 아무것도 하지 않은 경우보다도 파단신율이 증가하고, 편차도 감소한다.

- 유성윤활제를 사용하면, 분체윤활제를 사용했던 때보다, 파 단신율이 감소해 편차도 커진다.

또, 다이캐스팅 조건마다 와이블(Weibull) 분포를 Fig. 8 Fig. 11에 나타낸다. 
와이블 플롯 중에서 기울기가 큰 만큼, 그 재료의 신뢰성이 높다고 할 수 있다. 예를 들어 Fig. 8에서 표준재의 경우, 인 장강도가 $0.35 \mathrm{GPa}$ 정도이면 약 $5 \%$ 의 확율에서 밖에 파괴되지 못하고, $0.4 \mathrm{GPa}$ 정도에 다다르면 $99 \%$ 이상의 확율에서 파괴 한다. STL5s재의 경우, 인장강도가 $0.25 \mathrm{GPa}$ 에서 약 $20 \%$ 의 확율로 파괴하고, $0.3 \mathrm{GPa}$ 에서 약 $80 \%$ 의 확율로 파괴한다고 읽을 수 있다. 기울기가 작을수록 어느 응력에서 파단하는지 모르기 때문에, 신뢰성이 낮다고 말할 수 있다. 또, 일반 구조 용강의 기울기가 20 40이라고 말해지고 있다.

Fig. $8 \sim$ Fig. 11 의 결과를 정리하면, 이하와 같다.

- STL 이 긴만큼, 강도의 신뢰성은 낮아진다.

- 유성윤활제를 사용하면, 분체윤활제를 사용한때보다, 강도의 신뢰성이 낮아지지만, STL의 변화만큼 강도의 신뢰성에 끼치는 영향은 크지 않다.

- 개재물이 많아진 만큼, 강도의 신뢰성은 낮아진다.

- 금망의 사용에 따라, 개재물을 첨가한 채 아무것도 하지 않은 경우보다도, 강도의 신뢰성이 높아진다.

- STL이 긴만큼, 파단늘어짐의 신뢰성이 낮아진다.

- 유성윤활제를 사용하면, 분체윤활제를 사용했던 때보다, 강 도의 신뢰성이 낮지만 STL의 변화만큼 강도의 신뢰성에 미치 는 영향은 크지않다.

- 개재물이 많아질수록, 강도의 신뢰성은 낮아진다.

- 금망의 사용에 따라, 개재물을 첨가한 채 아무것도 하지 않은 경우보다도, 강도의 신뢰성이 높아진다.

- STL이 길수록 파단신율의 신뢰성이 낮아진다.

- 유성윤활제를 이용하면 분체윤활제를 이용한 때보다 파단신 율의 신뢰성이 낮아지지만 STL의 변화만큼 파단신율의 신뢰성 에 미치는 영향은 크지않다.

- 개재물이 많아질수록 파단신율의 신뢰성은 낮아진다.

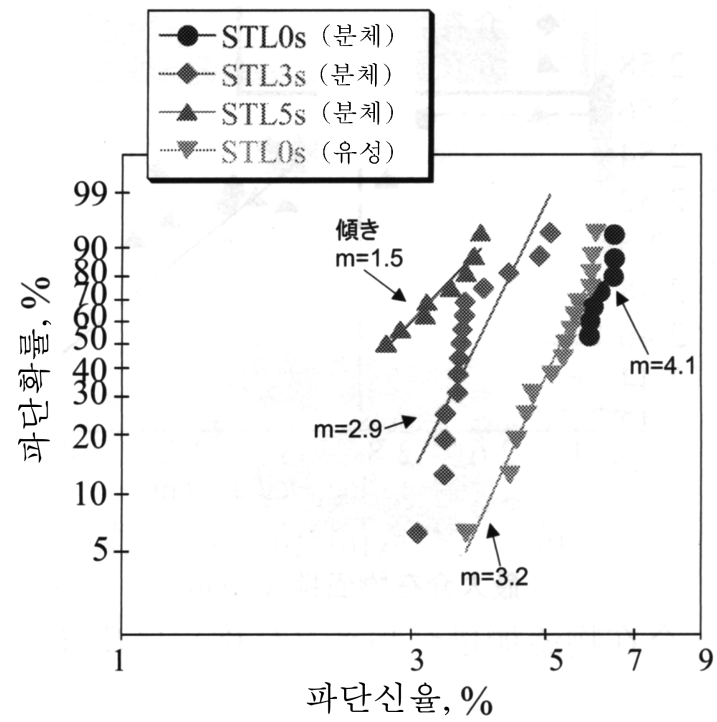

Fig. 9. STL과 윤활제가 파단신율의 신뢰성에 미치는 영향.
- 금망의 사용에 따라 개재물을 첨가한 채 아무 것도 하지 않은 경우보다도 파단신율의 신뢰성이 높아진다.

이상의 결과로 부터, 전보 [1]에서 시사된 유지로중의 개재 물량을 낮게 누를 필요가 없는 것은 아닐까 하는 가능성은 부 정되었다. 용해로중의 개재물은, 최종적 제품의 강도와 신율을 악화시키는 것을 알았다. 또, 파단칠층이 강도와 신율에 끼치는 영향은 개재물 이상으로 크다고 추측된다.

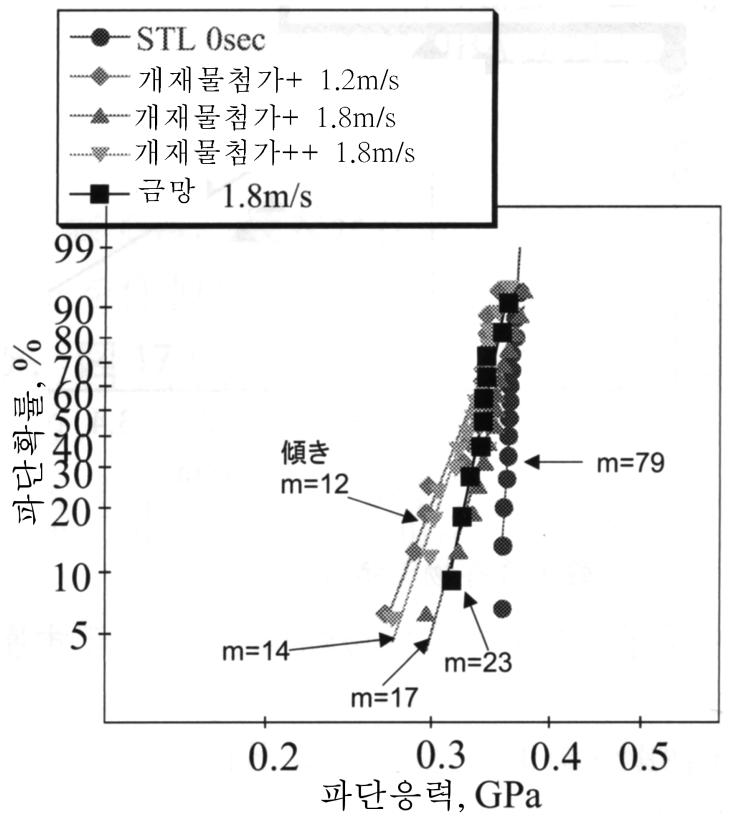

Fig. 10. 개재물첨가량이 인장강도(공칭)의 신뢰성에 미치는 영향.

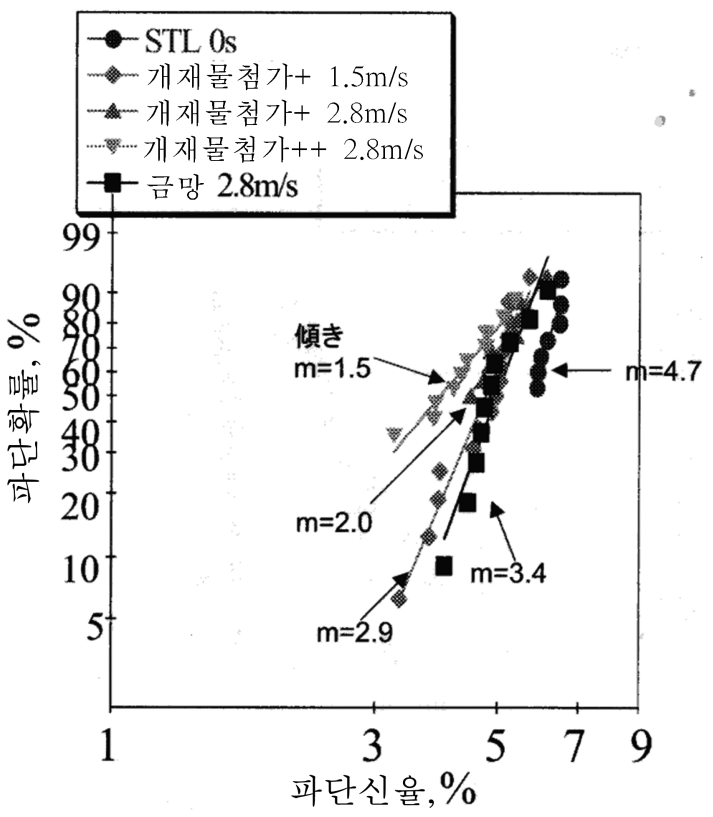

Fig. 11. 개재물첨가량이 파단신율의 신뢰성에 미치는 영향. 


\section{$4.2 \mathrm{ADC} 12$ 합금 다이캐스팅중의 개재물면적이 기계적 특성에 끼치는 영향}

결함을 최대주응력방향으로 수직한 면에 투영한 면적의 평방 근은, 강도에 가장 영향을 끼치다고 시사되고 있다 [2]. 파괴기 점이라고 판단되어진 개재물이 기계적 특성에 끼치는 영향을 루트영역을 사용해 조사하고, 기계적 특성에 영향을 끼치지않는 개재물 사이즈의 경계를 구했다. 또, $\sqrt{a r e a}$ 의 수치를 사용해 서, 2.1 항목에서 전술한 $K_{\mathrm{I}}^{*}\left(\fallingdotseq K_{\mathrm{IC}}\right)$ 에 대해서도 고찰했다. 개재물첨가량이 강도, 파단신율에 끼치는 영향을 나타내는 루 트영역을 Fig. 12, Fig. 13에 나타낸다. Fig. 12, Fig. 13로부 터, 이하의 것을 알았다.

- 개재물의 면적이 큰 만큼, 강도, 신율이 감소한다.

- 최대 개재물면적을 대강 $5 \times 10^{4} \mu \mathrm{m}^{2}$ 정도이하(직경 환산 약 $250 \mu \mathrm{m}$ 이하) 로 억제하면, 강도와 신율이 개재물 면적에 의존하지 않게 되고, 일정의 값에 수렴한다. 다만, 이 값은 냉 각속도와 조성에 의존한다고 생각 할 수 있기 때문에, 주의가 필요하다.

\section{3 개재물의 해석}

개재물의 화학조성을 해명하기 위해, 파면에 있어서 파괴기점

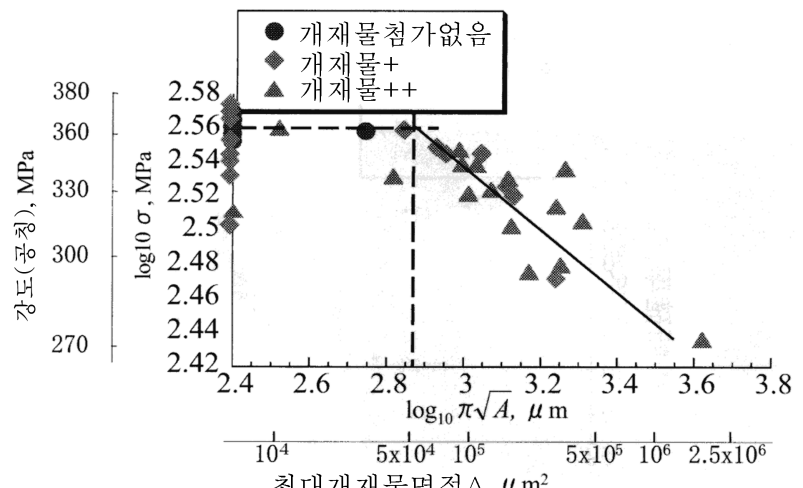

Fig. 12. 개재물첨가량이 강도(공칭)에 미치는 영향.

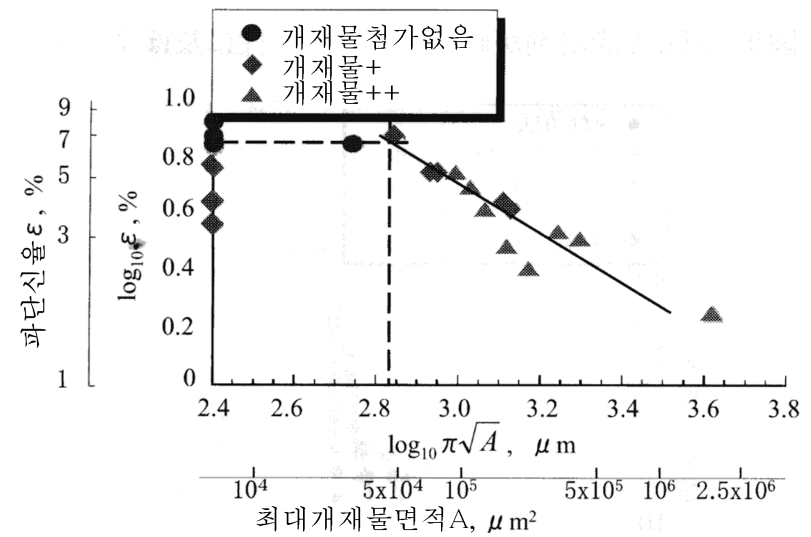

Fig. 13. 개재물첨가량이 파단신율에 미치는 영향.
이라고 인정되는 개재물의 원소를, $\mathrm{EDS}$ 를 사용해 조사했다. 개재물과 그 주변의 조직사진과 $\mathrm{EDS}$ 의 측정결과를 Fig. 14 Fig. 16 에 나타난다.

확인된 개재물은, 검출된 원소로부터, 규소의 산화물과 알루

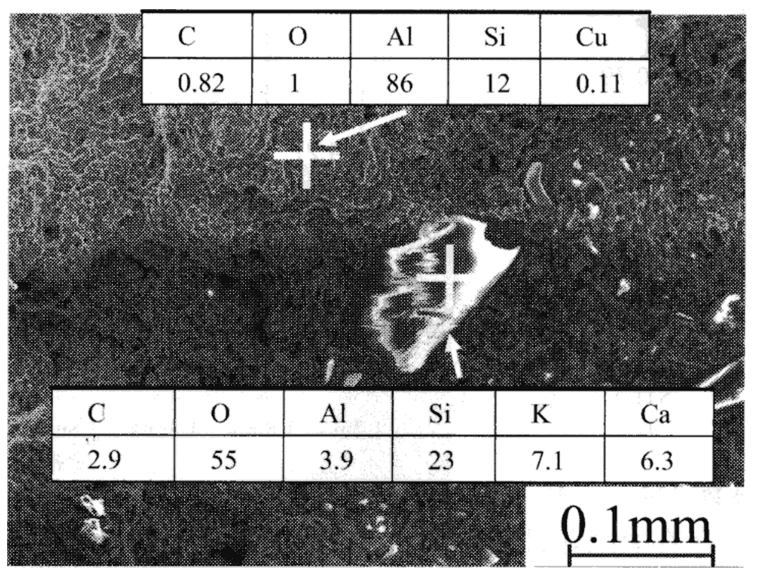

Fig. 14. 개재물 및 근방의 화학성분 $\operatorname{mass} \%$ (개재물 $++1.8 \mathrm{~m} / \mathrm{s}$ ).

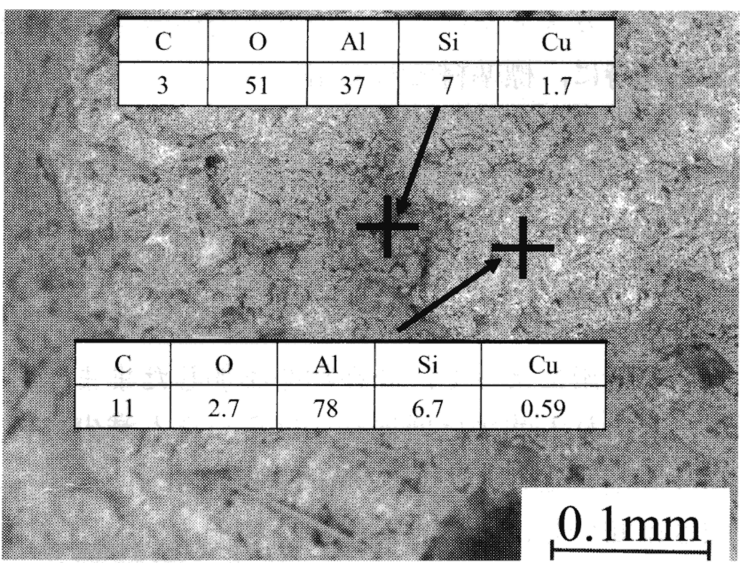

Fig. 15. 개재물 및 근방의 화학성분 mass\%(STL0s윤활제유성).

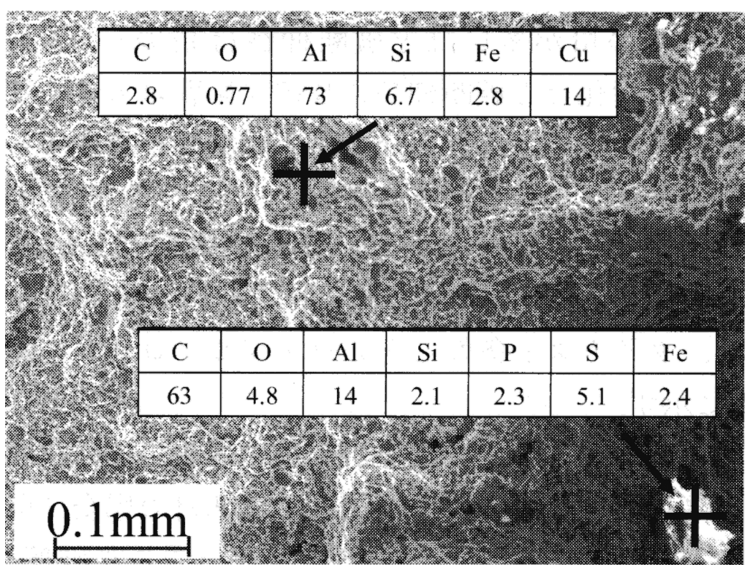

Fig. 16. 개재물 및 근방의 화학성분 $\mathrm{mass} \%$ (개재물 $++1.8 \mathrm{~m} / \mathrm{s}$ ). 
미늄의 산화물 및 알미늄의 탄화물이라고 생각된다.

\section{5. 고 찰}

본장에서는, $K_{\mathrm{I}}^{*}\left(\fallingdotseq K_{\mathrm{IC}}\right)$ 에 대한 고찰을 행해, 2.1 항목에서 전 술한 대로 $K_{\mathrm{I}}^{*}$ 은 재료의 고유치, 결함의 면적에 따르지 않고, 일정치이며, 거의 $K_{\mathrm{IC}}$ 와 동등치라고 보고 되어지고 있다 [3]. 본 실험에서는, 최대개재물의 면적을 사용해 루트영역 플롯을 제작했다. 면적의 증가에 따라 인장 강도는 감소했지만. Fig. 17 에 나타난 것과 같이, $K_{\mathrm{I}}^{*}$ 의 값도 증가하는 경향을 나타내어, 일정의 값이 되지않는다.

따라서, $K_{\mathrm{I}}^{*}\left(\fallingdotseq K_{\mathrm{IC}}\right)$ 의 값이 의존 하고 있는 것은 개재물 사 이즈와는 다른 별도의 수치는 아닐까 하고 생각했다. 村上들은 강의 경우, 파괴기점의 개재물 주변에 검게 보이는 부분이 발 생하고, 그것을 ODA (Optically Dark Area)라고 정의하고있 다 [9]. 이번에 실험했던 $\mathrm{ADC1} 12$ 합금의 경우에는, Fig. 18에 나타내듯이, 파괴기점의 개재물 주변에 하얗게 보이는 부분이 관찰되어지기 때문에 그 부분을 OBA(Optically Bright Area) 라고 정의한다. $\mathrm{OBA}$ 와 그 주변부의 $\mathrm{SEM}$ 사진을 관찰하면, $\mathrm{OBA}$ 의 외부는 연성의 파면인 것에 대해서, $\mathrm{OBA}$ 부는 취성의 파면이다.

여기에, $K_{\mathrm{I}}^{*}\left(\fallingdotseq K_{\mathrm{IC}}\right)$ 의 가치와 상관하고 있는 것은 개재물만의

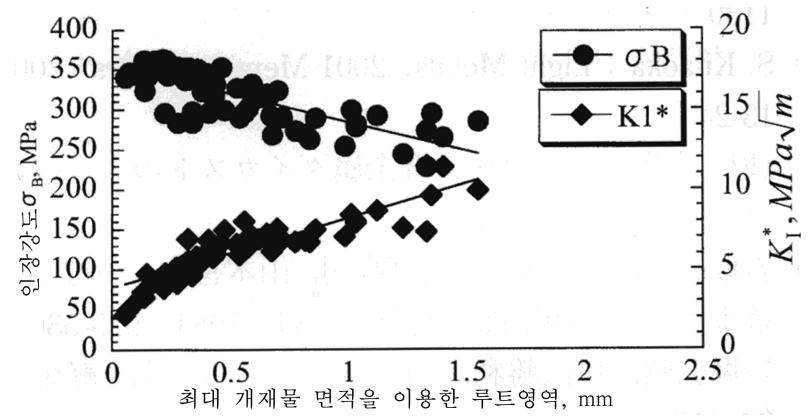

Fig. 17. $\sigma_{\mathrm{B}}, K_{\mathrm{I}}{ }^{*}$ 과 최대 개재물 면적을 이용한 루트영역과의 관 계.

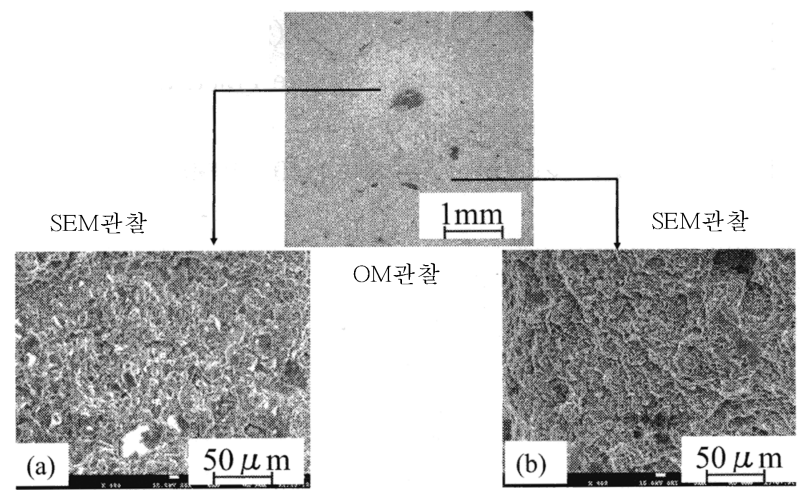

Fig. 18. $\mathrm{OBA}$ 의 $\mathrm{SEM}$ 관찰사진. (a) $\mathrm{OBA}$, (b) $\mathrm{OBA}$ 외주부.

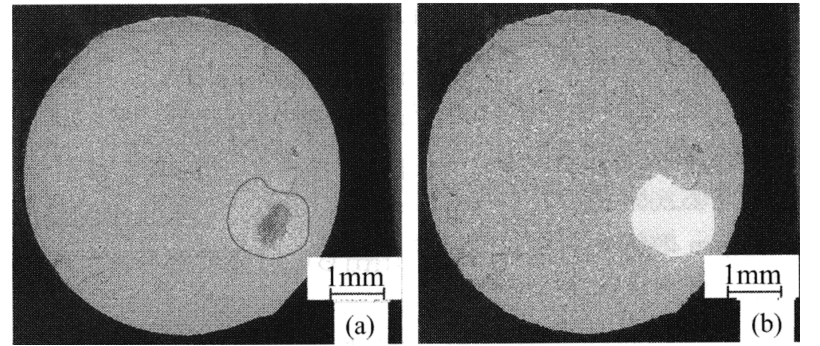

Fig. 19. OBA면적의 측정 예. (a) 측정전, (b) 측정시의 도포사진.

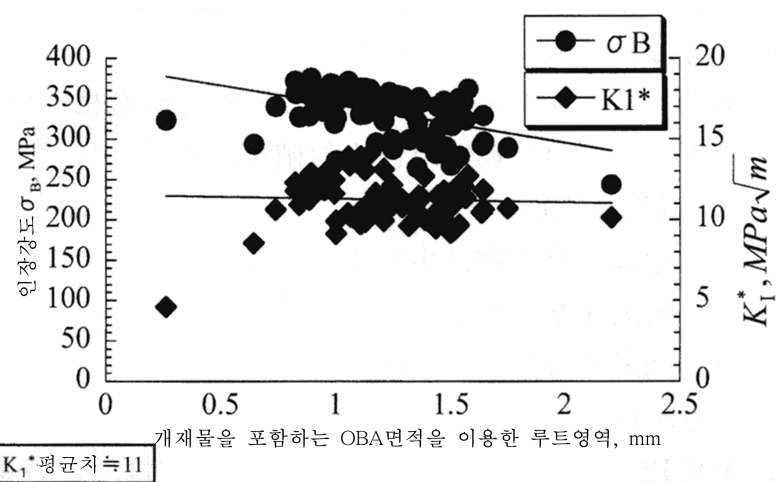

Fig. 20. $\sigma_{\mathrm{B}}, K_{\mathrm{I}}$ 과 개재물을 포함하는 OBA 면적을 이용한 루 트영역과의 관계.

면적은 아니고, $\mathrm{OBA}$ 을 포함한 면적이 아닐까하고 추측했다. 파면에 파괴기점이라 인정되는 개재물의 주위의 $\mathrm{OBA}$ 를 광학 현미경 사진으로 판단하고, 면적을 측정했다. 그 측정 예를 Fig. 19에 나타낸다. 루트영역 플롯을 그리기 위해서, OBA의 면적을 $\log _{10} \pi \sqrt{a r e a}$ 로 변환하고, 인장강도 및 $K_{\mathrm{I}}{ }^{*}$ 와의 관계 를 표현한 것을 Fig. 20에 나타낸다.

$\mathrm{OBA}$ 면적의 증가에 따라 인장강도는 감소하고 있지만, $K_{\mathrm{I}}^{*}$ 은 거의 일정의 값으로 수렴하고 있다. 평균치를 계산하면, 약 $11 \mathrm{MPa} \sqrt{\mathrm{m}}$ 에서, 山田들의 연구에서 얻어진 $K_{\mathrm{I}}^{*}$ 의 값(11정도)와 동등하다 [3].

$K_{\mathrm{I}}^{*}=K_{\mathrm{IC}}$ 이라고 가정하고, $K_{\mathrm{IC}}$ 의 산출식 $\left(K_{\mathrm{IC}}=\mathrm{Y} \sigma_{f} \sqrt{\pi \alpha}\right)$ 에 이 결과를 대입하면, $\mathrm{a} \fallingdotseq 315 \mu \mathrm{m}, 2 \mathrm{a}=630 \mu \mathrm{m}$ 이 된다. 하지 만 이것은, 4.2 항목의 결과인 최대 「최대 개재물 면적을 개략 $5 \times 10^{4} \mu \mathrm{m}^{2}$ 정도이하(직경환산약 $250 \mu \mathrm{m}$ 이하)로 억제하면 강도와 신율은 개재물 면적에 의존하지않게 되고, 일정 값에 수렴한다.」 라면 모순한다. 이유는 확실하지 않지만, 안전면에 서 판단하면 $250 \mu \mathrm{m}$ 의 값을 판단 기준으로 해야만한다고 생 각한다.

\section{6. 마무리}

본 연구에서는 JIS ADC12 알루미늄합금 다이캐스팅중의 개 재물, 파단칠층이 기계적 특성에 끼치는 영향에 대해서 검토 
했다. 이상의 것을 총괄하면,

1) 용탕, 다이캐스트 프로세스중의 관리와 제어에 대해서, 강 도, 신율의 신뢰성 및 절대치를 높이기 위해서는

- STL은 짧게

- 원탕의 개재물은 적게, 작게

- 사출속도는 빠르게

· 윤활제는 유성보다 분체

의 편이 좋다.

2) $\mathrm{ADS} 12$ 합금 다이캐스팅에 있어서 개재물은 규소의 산화 물과 알루미늄의 탄화물 및 알미늄의 탄화물이라고 생각된다.

3) 이 연구의 주조조건에서 얻어진 시험편에 대해서는, 최대 개재물 면적을 $5 \times 10^{4} \mu \mathrm{m}^{2}$ 정도 (직경환산으로 $250 \mu \mathrm{m}$ 정도) 이하로 억제하면, 강도와 신율은 일정의 값에 수렴한다. 단지, 이 값은 냉각속도와 조성에 의존한다고 생각할 수 있기 때문 에, 주의가 필요하다.

$$
\sqrt{\text { area }} / \sqrt{A_{0}} K_{I, A} / \sigma \sqrt{\pi}
$$

\section{감사의 말}

이상의 연구는, 2006 2008년도 다이캐스팅의 고품질화 연구 부회 (安齋浩一지부회장), 2009년도부터의 다이캐스팅의 품질 및 생산성 향상 기술연구부회(神戶洋史지부회장) 공동의 연구 테마로서, 北岡山治박사의 지도하에서 실험된 것이다. 양 연구 부회의 참가위원에 깊은 감사의 뜻을 표합니다.

또, 료비(주), 일본경금속(주)에서는 많은 협력을 받았습니다. 깊은 감사의 뜻을 표합니다.

또, 본 연구의 데이터 해석에는, 현 대련이공대학의 陣史씨로 부터 많은 협력을 받았습니다. 깊히 예를 표합니다.

\section{참고문헌}

[1] 高木航, 吉田誠 : 鋳造工学, 83（2011）579

[2] 村上敬宜, 遠藤正浩：日本機械学会論文集（A), 49 (1983) $127-136$

[3] 山田耕二, 宮川進, 吉川澄: 日本機械学会論文集 (A 編), 68 (2002) 39-44

[4] 村上敬宜, 野本哲志, 植田徹, 村上保夫, 大堀学: 材料, 48 (1999）1112-1117

[5] 下田秀夫 : 鉄鋼製品破損事故の調查 - 解析法之原因の 究明, (1996)

[6] Y. Furuya, H. Hirukawa, T. Kimura, M. Hayaishi : Metallurgical and Materials Transactions A, 38 (2007) $1722-1730$

[7] Y. Murakami, T. Nomoto., T. Ueda. : Fatigue Fract. Eng. Mater. Struct., 22 (1999) 581-90

[8] 北岡山治：鋳造工学, 75 (2003) 800-806

[9] Y. Murakami, J. Nagata : Transactions of the Japan Society of Mechanical Engineers A, 72 (2006) 11231130

[10] S. Kitaoka : Light Metals, 2001 Meraux Legers (2001) 13-24

[11]（財）素形材センター：軽金属ダイカストの生産技術, (1993)

[12] 岩堀弘昭, 戸沢勝利, 浅野高司, 山本善章, 中村元志, 橋本正興，上西始郎：軽金属，34（1984）525-530

[13] 岩堀弘昭, 戸沢勝利, 山本善章, 中村元志 : 軽金属, 34 (1984) 389-394

[14] 鈴木宗男, 古本一之 : 軽金属, 21 (1971) 36-45

[15] 松山晋作：遅れ破壊,（1989）

[16] 村上敬宜, 長田淳治：材料, 54 (2005) 420-427

[17] Nishijima, K. Kanazawa : Fatigue Fract. Eng. Master. Struct., 22 (1999) 601-607

[18] 神戸洋史, 多胡博司 : 素形材, 40（1999）1-4 